\title{
Jesus and Ethnicity: A Theological Reflection on the Message of John 4:1-24
}

\author{
Livingstone Yao Torsu \& Francis Brown'1 \\ ${ }^{1}$ Department of Theology, Heritage Christian College, Accra-Ghana.
}

\begin{abstract}
The message of Jesus Christ is to save everyone irrespective of tribe, culture, geographical location, and language. His main purpose is to restore the human relationship with God. In view of that, the study employed an analytical approach to finding out how Jesus dealt with ethnicity in the propagation of the message of God (the Gospel) to deduce relevant messages across ethnic boundaries. As a result of this, the study revealed that Jesus did not rule out the role of culture in the propagation of the message. It is observed that culture is knowledge, language, values, and customs. Thus, the message demonstrates how Jesus dealt with the Samaritan woman. Jesus communicated to the woman in simple and understandable language. His respect and love for the woman at the well and her view as part of values by requesting water from her suggests that he did not do away with the essence of values and customs. Therefore, this study suggests that Christians do likewise in the quest to disseminate the message of God, instead of promoting ethnicity which will end up limiting the message to a particular group of people. This study revealed that the best way to effectively carry the message across is to achieve the goal of the great commission by engaging people in terms of cultural relativism rather than ethnocentrism.

(c) 2020 The Authors. Published and Maintained by Noyam Publishers.

This is an open access article under the CCBY license (http://creativecommons.org/licenses/by/4.0/).
\end{abstract}

\section{Correspondence:}

Livingstone Yao Torsu. Email: rev.livingstoneyaotorsu@

yahoo.com

\section{Manuscript}

Received 13th May 2020,

Accepted 27th July 2020,

Published online 7th August 2020.

\section{INTRODUCTION}

Ethnocentricism is a situation that leads one to think that his or her culture is better than others'. If this view is subscribed to, it will hinder development in many sectors of life. For instance, 'Christian mission calls men and women from every cultural, religious, and social background to confess that "Jesus is Lord," thus embracing Jesus of Nazareth as Christ and Saviour, placing all of life under his authority, and preparing for his kingdom. ${ }^{2}$ This is a call to the most radical personal change, ultimately impacting every aspect of life. ${ }^{3}$ Preceding citations underscore the core value of mission which calls for men from every cultural religious and social background. This shows that a mission such as this, known as the Christian mission, has no boundary or limited scope of work. In other words, the mission of this kind must not be limited by culture, religion, or social background. The mission must overcome the boundaries of culture, religion, and social background. Again the above citation speaks about the purpose of mission which is that men and women confess that Jesus is Lord and surrender to him as a Savior. Sufficing to that is men and women should be able to go through a radical personal change. Thus, it is expected that the mission must result in the personal change of life. Per the goal of the mission, it is imperative for the missionaries who are mandated to carry missions across the boundaries of cultures, religions, and social background to tailor their messages such that it could be culturally and religiously friendly to enable individuals and people to embrace Christ without reservation.

Miller gives five indicators that help to define ethnicity. These indicators permit a clearer understanding of the concept of ethnicity and paves ways through which the gospel can permeate ethnic barriers. First is the Social activities of social groups - pointing to the customs, practices, language, occupation, and other factors that set a group as distinct from the other. ${ }^{4}$ This somehow influences the "we", "us" "they", "them" dominance in social interactions. With this feature of the social group in mind, the gospel communicator has to exhibit some features of the group to have a sense

\footnotetext{
J. C. Miller, Ethnicity in the Hebrew Bible: Problems and Prospects, 6, (2008), 170-213.https://doi.org/10.1177/1476993X07083627

3 Craig OTT Stephen J. Strauss and Timothy C. Tennent, Encountering Theology of Mission complete the bibliographic information and add page number Biblical Foundations, Historical Developments, and Contemporary Issues. (Grand Rapids, Michigan: Baker Academic, 2010), 56.

4 Miller, Ethnicity in the Hebrew Bible, p. 170-213.
} 
of the "we feeling" before communication can be effective. ${ }^{5}$ Second is the Changing nature of society. Miller states that "society is reconstructed as it meets new environment and experiences." The changes occur to meet further social and political agendas. In this regard, the missionary can better execute his mission if the gospel is communicated as part of the new experiences that the society is moving towards. ${ }^{6}$ A society without Christ is a society without life and will die miserably (Matt. 3:7-11). ${ }^{7}$ The third is the Solidarity of the social group - this shows how a group is attached and their reaction to threats. The gospel is made to understand that it is not a threat but a reliever from eternal condemnation (Mark 16:15-16). ${ }^{8}$ Next is the Formation of social groups. Miller agrees with Hall that the formation of an ethnic group is formed at two levels; aggregative self-definition, which defines how a group sees others in relation to them, and oppositional self-definition, which defines how a group sees other groups in opposition to them. ${ }^{9}$ The gospel will permeate through the fabric of an ethnic group if it is understood as not an opposition to the culture but a complement to what they already believe (Acts 17:23-28). ${ }^{10}$ The final indicator is Permeability which refers to breaking through social boundaries to assimilate. The gospel is to be used as a bonding agent that breakthroughs and brings cultures together to bow to one God. Jesus Christ exemplifies this by dying on the cross to bring Israel and Gentiles together as one people to worship. ${ }^{11}$

Perhaps this might be the view that influences the view of Lamin Sanney to state that:

The mission is essentially praxis, and that entails not only upholding the truth but also relationship and communication. Whatever the question about the essence of the message, the specific and the concrete foundations of the mission are set in cultural particularity and historical specificity. Christianity is a religion of historical events that are decisive in the meaning people ascribe to them. ${ }^{12}$

In this statement, Sanney seems to emphasizethe people's understanding of the message which is culturally saturated and embalmed. His concern is not only necessary but so much expedient to be considered in mission. Because without that there will not be good communication, let alone provide a good atmosphere for relationships which is the key element of the mission.

\section{Text Reading: John 4:1-24}

The issue of ethnicity is very obvious in verse 9 where the woman made ethnocentric statements that "How is it that you, a Jew, ask a drink of me, a woman of Samaria?" because Jews do not share things in common with Samaritans. In these statements, the woman discloses their identity and compares themselves to the Jew negatively. This is expressed

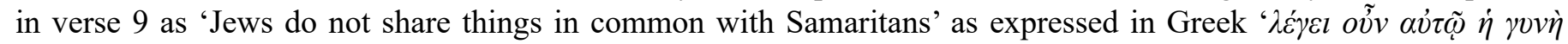

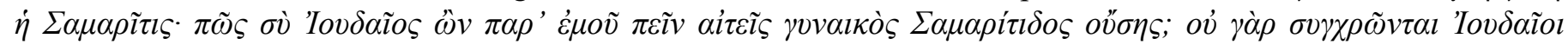

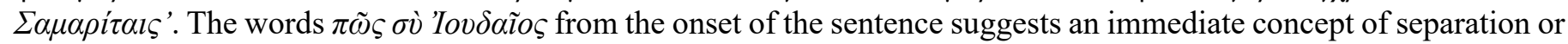
difference from the speaker who is assumed to be the woman. Such a view was fully expressed in the latter end of the

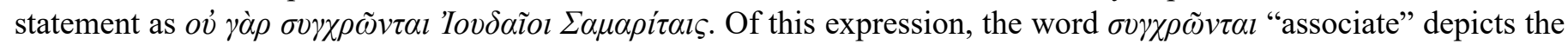
distinctive factor that Samaritans do not associate with the Jews. Thus, the ethnicity concept can be deduced from this particular expression in verse 9. But significantly, Jesus's statement points out that in as much as ethnicity is important in terms of dealing with one another, God's mission goes beyond ethnicity differences. The expression $\dot{\alpha} \pi \varepsilon \kappa \rho i \theta \eta$ 'I

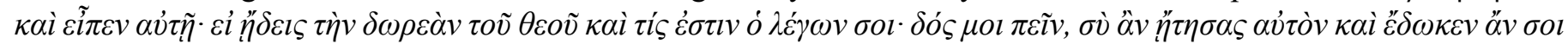
$\nu \delta \omega \rho \zeta \tilde{\omega} v$ ("Jesus answered and said 'If she knew the gift of God, and who it is that is saying to her, 'Give me a drink,' she would have asked him, and he would have given her living water" (NRSV John 4:10). In this expression, the word

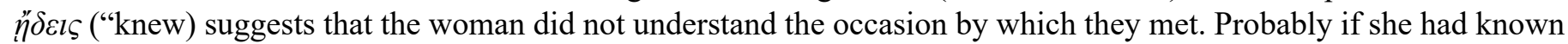
that God planned to meet at that place, she would have easily accepted to give him the water. This brings to the fore that

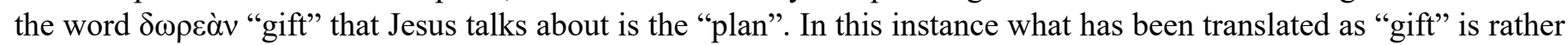
the "plan". Thus, $\delta \omega \rho \varepsilon \dot{\alpha} v$ should be understood as the "plan" rather than the "gift". In this case, the author suggests that Jesus lived above ethnicity. This is seen in the expression that the plan of God has nothing to do with ethnicity let alone be limited. It also appeared that Jesus broke the boundaries of culture to engage in conversation with the woman in their territory. The woman was insisting on cultural issues such as the bucket and the deepness of the well. She was

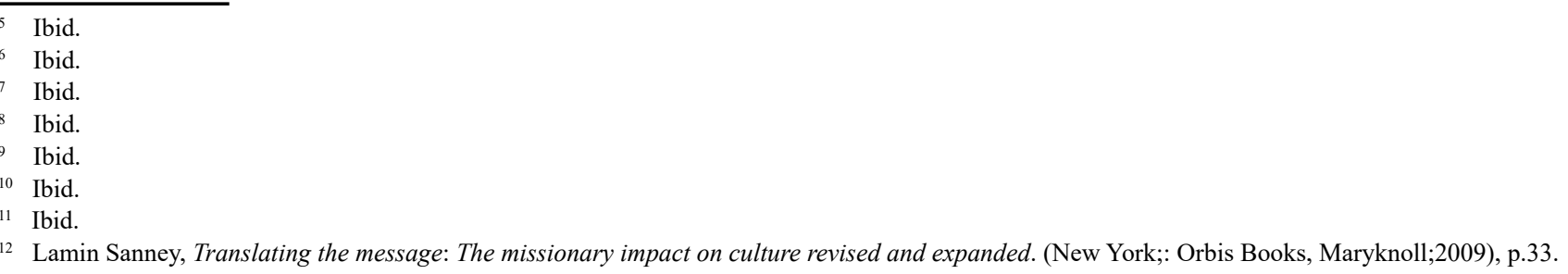


also viewing water at its natural state while Jesus was considering it as life. Here the author combines the parable and statement of reality to depict a concept. Thus, in one aspect the word $v \delta \omega \rho$ (Joh 4:10) is referred to as the natural water while in the other aspect it is referred to as abstract representing eternal life. This also brings to the fore the style of the author and his rational views which is about the philosophical expression among the Greeks. Where Plato and Aristotle are highly acknowledged in their discourse about reality and form. If this concept of form and reality should be used, then the natural form can be referred to as the reality whereby the form will be referred to as eternal life. This understanding could be applied to verses $7,10,11,13,14,15$, for natural water could be deduced from the expression in verse 7 and 11. In verse 7 and 11 and $13 v \delta \omega \rho$ is natural water as displayed in the texts. For instance, in verse 7 the

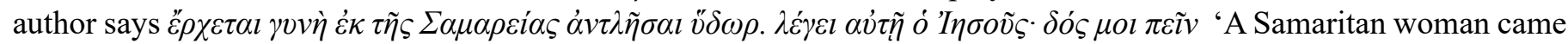
to draw water, and Jesus said to her, "Give me a drink." This understanding is deduced from the verse with reference to the preceding verse 6 where specific allusion is made to the well of Jacob. In verse 6 the awareness is made that Jacob's well was there, and Jesus, tired out by his journey, was sitting by the well. It was about noon. Thus, the well made it clear to think that this water is natural. Just as the use of bucket also explains the nature of water the author referring to. Apart from the use of bucket referring to the natural status of the water, the bucket is also an item displaying culture value. For the woman it is the bucket that can be used to fetch water, besides that will be a different thing or meaningless things. So her ignorance is expressed as "the woman said to him, Sir, you have no bucket, and the well is deep. Where do you get that living water? (NRSV John 4:11). In verse 13 and14 the author made contrasting views about the natural water and the eternal life suggesting that one has a limited duration whiles the other is infinitive. The verses 13 and 14 are read as Jesus said to her, "Everyone who drinks of this water will be thirsty again, but those who drink of the water that I will give them will never be thirsty. The water that I will give will become in them a spring of water gushing up to eternal life." The new paradigm introduced in verse 10 has now been explained in verse 14. This led to the woman's admission that she needed eternal life in verse 15 . The woman said to him, "Sir, give me this water, so that I may never be thirsty or have to keep coming here to draw water"(NRSV).

Of the above discourse, some mission tools have emerged naturally in the conversation between Jesus and the Samaritan woman. These are the personalities involved, cultural relevance which comprises norms and values in terms of creating awareness for Jesus about the relationship between the Jews and Samaritans by using local items such as a bucket, style of engagement such as communication skills. Among the cultural relevance are values such as respect and love that Jesus accords the woman. As it is noted that:

Cultural values are these collective conceptions of what is considered good, desirable, and proper-or bad, undesirable, and improper - in a culture. They indicate what people in a given culture prefer as well as what they find important and morally right or (wrong). Values may be specific, such as honoring one's parents and owning a home, or they may be more general, such as health, love, and democracy. ${ }^{13}$

That is why one cannot downplay the cultural values in the mission work of God. Jesus did not undermine the culture of the woman by asking her to fetch him water to drink at the well. Despite the way the woman thought about herself, Jesus was able to influence the woman. It is therefore no wonder that Jesus was able to convince the Samaritan woman because the woman saw that she was accepted by Jesus. This is an indication that though 'values influence people's behavior ${ }^{14}$ to think in a particular way it can be influenced. For Example, just as Jesus influenced the cultural view of the woman at the well. The strategy used by Jesus to influence the woman at the well has become a relevant tool in mission. These tools have now emerged for successive believers to be abreast with to engage in an extensive mission.

\section{Ethnicity and mission}

On mission Russ Parker and Roy Lawrence submit that:

Parish Mission is a day-by-day ingredient of church life. If Christians believe that the gospel can be a saving and healing difference to the hurts, follies, and sins of our nation and that we are called to make this difference known and available, then mission must be worked into our ordinary church structures and programs. We must not wait for the occasional 'parish mission' to do this work for us. ${ }^{15}$

The impression created by the above submission of Parker and Lawrence suggests that mission should not be limited to a special time frame rather it must be a daily affair. In other words, a mission must simply be a day by day activity. This,raises the question of how to engage in mission and what will help to efficiently execute it. Once it is about conveying the gospel to the people, it needs tools for execution. Tools in mission in this context refer to the elements

\footnotetext{
13 Richard. T. Schaefer, Sociology 7th edition (New York: McGraw-Hill Companies, Inc, 2001), 74.

14 Ibid.

15 Russ Parker and Roy Lawrence, Healing and Evangelism (London: BPC Paperbacks Ltd, 1996), 99.
} 
that involve the sharing of the words of God with people. The tools realized in the earlier discourse between Jesus and the Samaritan woman are "acceptance", "communication skills" and "cultural relevance". Acceptance reflects its light in terms of ignoring the existing differences to maintain a relationship. Through that, one ends up establishing a rapport. To achieve this, one needs to engage in conversations. This is where communication skills become relevant. In such a situation the use of language plays a major role. Since there is a general agreement that language comprises both verbal and non-verbal elements, culture relevance also comes into play because in most cases language thrives not only on verbal expression but it works together with human attitude, character which includes temperament, love, patience, perseverance, and local materials to make meaning.

\section{Relationship and Communication}

A relationship is an outcome of good communication between two or more people. Therefore, relationships cannot exist without good communication. Communication is a dialog, an open message, an encouragement, a process of sharing news and interesting information. ${ }^{16}$ That means communication is the exchange of ideas or information. How this information is shared is the language. Language is an expression of ideas verbally or nonverbally. Grace Yawo Gadagbui notes that "in communication, we use either verbal (speech) or non-verbal language or both simultaneously. A successful language results from the integration of its form, its content, and its use in the normal pattern of development." ${ }^{17}$ It is important not to take things for granted when communicating with others whether verbally or nonverbally. Just as Gadagbui puts it, "in non-verbal forms, we use smiles, handshakes, style of dress, hairstyle and choice of colour, sign language, braille and written language, artwork gestures, miming, drama, frown or yawn"18. She adds that "all these messages provide information to be interpreted within their context". ${ }^{19}$ Thus, to Gadagbui every action carries a message therefore each of them provides information within a context. It is however important to note that "language is also the garment that gives shape, decorum, and vitality to conscious life, enabling us to appreciate the visible texture of life in its subtle, intricate variety and possibility". ${ }^{20}$ By this, language is seen as relevant to humanity so much so that it does not only express the views or feelings of people but it also provides one's identity. Perhaps this might have informed the view that "lexical resources must be deepened with the force of usage, custom, and tradition to become meaningful, particularly if we want to represent the dynamic quality of life" ${ }^{21}$. With this language argument, one has no option to reason out than to make an inference that language has much to do with culture. Because to some extent various forms of actions are culturally understood. Emmanuel Asante notes that the missionaries were of the view that since language is the gateway to the culture of any given people, it would be wrong to introduce "converts to any western language since this was likely to expose them to undesirable western influences" and hinder the development of indigenous Christian expression. ${ }^{22}$ This shows the relevance of language in culture and mission.

\section{Culture and Mission}

It is noted that sociologists regard culture as a central ingredient in human behaviour. ${ }^{23}$ Culture is the knowledge, language, values, customs passed from one generation to the next in a human group or society. ${ }^{24}$ Culture is generally understood as a way of life. In a similar vein, Asante looks at it in a broader perspective by taking religious life as equally important as other segments of human life and in effect provides a lengthy description about culture that: humans confront their living environment as a puzzle; a mystery that needs to be unraveled; a chaotic condition that calls for order; a meaningless situation that demands meaning; a project that needs to be tackled: a friend that needs to be interacted with; a foe that must be confronted and defeated; a divine reality that draws reverential fear and calls for deference; a revelatory event that beckons humans to commit themselves to a divine reality understood as the creator. As they confront the environment from these different perspectives, they create culture. Thus, the natural thing a group of people who find themselves in a particular environment or geographic space do is to evolve a shared life and establish a social framework within which they can function as human beings. They do this by evolving certain values, practices, and institutions, in short; common forms or ways of life. ${ }^{25}$

\footnotetext{
16 Grace Yawo Gadagbui, Communication Disorders and Performance in Learning Environments (Accra, Ghana: Bunni Business \& Multi-Media Center, 2012), 1. 
In the aforementioned, citation culture is seen as something that is developed by people living in a geographical area. Such a thing is done naturally without any difficulty. In other words, such a thing becomes part and parcel of the people in the environment they live in. Out of such natural performances, certain values and practices are developed for identification. Despite some views that culture and Christianity are incompatible others hold the views that Christianity must go with culture to expand the mission of God. This is expressed vividly by Asante when he writes:

Opinions differ when it comes to the question of the relationship between Christianity and culture. One extreme position, which may be referred to as Christianity against culture maintains that Christianity has nothing to do with culture. According to this position, Christianity is acultural. Christians who espouse this position hold any Christian theologian flirting with anything smacking of 'culture' a suspect of infidelity in respect of Christian faith and practice. In reaction to this extreme position comes another extreme position, which may be designated as Christian in culture. Exponents of this position adopt an uncritical attitude toward anything that goes by the name culture. For them, Christianity is not poles apart from 'culture'. Everything culture is unquestionably acceptable. Christianity, according to the view in question, expresses itself in diverse cultures. ${ }^{26}$

The above citation provides conflicting views regarding the relationship between culture and Christianity. It appears that two groups of people have different views about the role of culture in terms of expanding the work of Christianity. The first group makes it clear that Christianity has nothing to do with culture. Therefore, it suggests that culture is against Christianity. The other group takes the opposite stance that culture and Christianity go together to make an impact. This view is relevant and expedient to be promoted because without culture how does Christianity make meaning and let alone make an impact on people's ' lives. Thus, culture is one of the major tools to be considered in terms of aiming at expanding the work of Christianity. The essence of culture is echoed in the words of Sanney. According to him:

'for the early Christians, there were two basic ways to proceed. One was to make missionary culture --in their case, the Mosaic code---the carrier and arbiter of the message. This we might call mission by diffusion. By it, religion expands through its founding cultural warrants and is implanted in other societies primarily a matter of cultural adoption. The other way was to institute the recipient culture as a valid and necessary locus of the proclamation, allowing the religion to arrive without the requirement of deference to the originating culture. This we might call mission by translation. ${ }^{27}$

In the above submission, Sanney enumerates two main major tools for a mission. These are mission by diffusion and mission by translation. He explains the first as a matter of expanding the religion by a means of cultural adoption and the second is explained as allowing religion to arrive without the need for difference in the original culture. Using these measures are very vital for missions. ${ }^{28}$

\section{Ethnicity impact on missions}

Under this section, the issue of how the mission is affected positively and negatively by ethnicity is discussed. The former result is about the outcome of the advantages of ethnicity while the later will enumerate its disadvantages. Though in many instances ethnicity turns to offer challenges to the society, it is however opined that "ethnicity in Africa is hardly an emerging reality that spells danger or doom in respect of the health of a nation. Ghana, for instance, has always been and will continue to be a multi-ethnic nation." ${ }^{29}$ This is an indication that ethnicity by nature has a tendency to pose danger to a nation but it can also be lived with on certain grounds. Asante describes Ethnic groups as;

Populations that have a sense of group identity based on a distinctive cultural pattern and, usually, shared ancestry, whether actual or assumed. Such a group has a sense of 'peoplehood' that is maintained within a larger society. Ethnicity feeds on "the belief that one's ethnic group constitutes a distinct people whose culture is and should be separate from that of the large society. ${ }^{30}$

Apparently, the issue of ethnicity is expressed with the goal of the mission. It also appears that the mission of Christ is not to be limited to a particular culture rather it is for all of humanity. On this basis, Jesus did not employ the tools that culminated in ethnocentrism. The biblical texts discussed above clearly show that the tools employed by Jesus were culminated in cultural relativism. Since cultural relativism views people's behaviour from the perspective of their own culture ${ }^{31}$ and treats them as such. In this case, the individual is granted an opportunity to understand another person within a cultural context without running him or her down because cultural relativism purposefully places a 
priority on understanding other cultures, rather than dismissing them as "strange" or "exotic." 32 This was what Jesus demonstrated to the Samaritan woman in their conversation. That is why whilst the woman was trying to play the game of ethnocentrism by saying the Samaritan and Jews do not share things in common, Jesus rather focused on his intention of employing cultural relativism. Cultural relativism stresses that different social contexts give rise to different norms and values. While cultural relativism does not suggest that one must unquestionably accept every cultural variation, it does require a serious and unbiased effort to evaluate norms, values, and customs in light of their distinctive culture. ${ }^{33}$

In the same way, tools can be described in relation to the goal of its usage. These people may belong to various ethnic groups but the target of Christ is to save them. But this could not be effectively done without certain skills and devices. Such skills and devices are classified as the tools in mission. Hence, tools in this paper refer to the strategies to carry out the mission of Christ. It is therefore imperative that the mission is carried across the ethnic background.

Sanney notes that ethnicity raises an acute paradox: how may the Church, Gentiles or others, rise to its missionary obligation unless it believes that its culturally-specific experience is in some fashion normative of the divine truth? $?^{34}$ Asante also posits that 'even though it cannot be denied that the early Christian missionary enterprise is a contributing factor to the fact of cultural alienation in Africa, it cannot also be denied that Christianity has contributed immensely towards the development of Africa. ${ }^{35}$

\section{Theological Reflections}

Anyone very familiar with the relationship between the Jews and Samaritans will admit the fact that a step taken by Jesus to win a Samaritan woman at the well (John 4:1-24), needs to be emulated for the avoidance of various challenges ethnicity creates in human life. The challenges like division, under-development, lack of promotion, and joblessness among people in the same area or community in many instances are the result of ethnocentricism. Even the challenges created by ethnicity graduates to conflict and war in places like the countries, cities, towns, and villages. Especially, among Africans, it is something that one cannot shy away from. This means that the concept of ethnicity is known among the Africans as diversity in nature. This view is skilfully express as "the African reality and, for that matter, the Ghanaian reality has always been characterized by ethnic diversity. ${ }^{36}$ Its effects on the continent and the countries seem to be inimical not only for African, for that matter the Ghanaians but to humanity as large in the globe.

For example, because the effect of ethnicity is inimical to humanity, discouraging it becomes a major concern for many people. Developmental projects may not see the light of day.

\section{Division}

The division is promoted by the concept of ethnicity. Since the motivating factor for ethnicity is a "belief that one's ethnic group constitutes a distinct people whose culture is and should be separate from that of the larger society." ${ }^{37}$ Holding this ethnic view is easy to promote better off attitudes towards someone or group culminate in separation from others. The issue for ethnicity expresses in the words of the woman at the well is believed to have originated "from the time of Eli, when he established a shrine in Shiloh. The case was exacerbated by David as he moved the shrine from Shiloh to Jerusalem.. ${ }^{38}$ Later, the condition of ethnicity was further carried out by Ezra after returning from exile in Babylon" 39 and was finally rooted under Nehemiah (Neh. 4:13). Salakpi notes that:

The final schism between the Jews and Samaritans did not come until the time of Nehemiah, and it was primarily on political grounds. Nehemiah had the opportunity to become a Persian official. Nehemiah hearing of the deteriorating Jewish community that had returned to Jerusalem after the exile, obtained permission not only to visit but to be its governor. To protect the community's purity, Nehemiah forbade intermarriages with those who remained on the land (Neh 13:13-28). p.1144.

Since Samaritans are the descendants of intermarriages, they were rejected by the Jews because of their inability to trace their genealogy. ${ }^{41}$

\footnotetext{
32 Ibid.

33 Ibid.

Sanney, Translating the message (Insert page number)

Asante, Culture, politics and development, p3.

Ibid 62

William Kornblum, Sociology in a changing World (Chicago: university of Chicago press, 1988), p. 293.

38 Alexander Salakpi, Do we still need this-Cultural Prejudice? A contemporary Study of John 4:1-42. In A Journal of African Biblical Studies. V.6.(Cape Coast; Ghana: Ghana Association of Biblical Exegetes, 2019),113.

39 R.T. Anderson and T. Giles, The Keepers, An introduction to the History and culture of the Samaritans,(Peabody:Hendricks Publishing inc., 2002$), 13$.

40 Salakpi, Do we still need this-Cultural Prejudice?p. 113.

${ }_{41}$ Warren W. Wiersbe, The Bible Exposition Commentary (Old Testament, Originally Published in 4 Volumes) Eastbourne, England: Cook Communications Ministries, 2004. C: $\backslash$ Program Files (x86)\Biblesoft $\backslash P C$ Study Bible $\backslash$ Refworks $\backslash b 00334$ BECommOT.JSR see further explanation, The Samaritans were a mixed race, part Jew and paart Gentile, that grew out of the Assyrian captivity of the ten northern tribes in 727 B.C. Rejected by the Jews because they could not prove their genealogy, the Samaritans established their own temple and religious services on Mt. Gerizim. This only fanned the fires of prejudice. So intense was their dislike of the Samaritans that some of the Pharisees prayed that no Samaritan would be raised in the resurrection! When His enemies wanted to call Jesus an insulting name, they called Him a Samaritan (John 8:48).
} 
These issues of tribal discrimination in politics, in marriages, religion, community, professions, etc, should be addressed with Jesus's approach to the Samaritan woman at the well. Others should not be avoided based on tribal or profession.

\section{Underdevelopment}

A community bedeviled with ethnicity retard developmental project. Asante put it nicely that ethnic diversity, per se, does not impede the healthy growth of a nation. ${ }^{42}$ This is a wise admission that growth and developmental project are weakened with a sense of ethnicity. This happens if people "make them less able to realize their hopes and needs for personal and community development" ${ }^{43}$ For developmental work to strive smoothly in a community everyone must be accepted as Jesus did for the Samaritan woman at the well. It appears that the woman held a view of ethnicity and wanted to separate herself from Christ. But Jesus breaks the barrier of ethnicity and accepts her. Once Jesus broke the barrier the mission of God was accomplished. The mission was accomplished not necessarily by his approach to the woman, but other things like good communication, acceptability of culture materials being used by the woman at the well. This re-echoes the view that people can work effectively if they are "free of trouble, major problems, oppression of all kinds, and threats as well as barriers to their future development." ${ }^{\prime 4}$

\section{Lack of promotion}

It is believed that in some professions where the concept of ethnicity is held, people's promotions are determined accordingly. A contact between Jesus and the Samaritan woman at the well ought to be a hallmark for engagement with people at all levels. In academia, religion, secular vocations, sense of ethnic bias should be avoided especially if it comes to promotion and elevation to a high position or office. It is very detrimental for a diligent and committed person serving in any of the above mentioned who is due for promotion. But it will never come on account of ethnic reasons. This attitude does not augur well in the light of Jesus' hallmark as found in the text. Instead of holding to the tenets of Jesus, ethnicity is given spectrum to drive on to make some people vulnerable in society. For example, "women encounter many barriers to advancement into corporate leadership positions, and these barriers include gender-based discrimination as well as unconscious gender bias". ${ }^{45}$ This is clear evidence about ill-treatments that are meted to the people based on the issues of ethnicity. The grounds on which women are denied certain privileges are explained in the definition of the unconscious gender bias. According to the International Labour Organization, "unconscious gender bias is defined as unintentional and automatic mental associations based on gender, stemming from traditions, norms, values, culture and/or experience. Automatic associations feed into decision-making, enabling a quick assessment of an individual according to gender and gender stereotypes". ${ }^{46}$

\section{Joblessness}

If a job market is created on the line of ethnicity, others are left jobless. The reason is that others will not get jobs despite qualification in skill or academic. A situation of this kind usually offers opportunities depending on cultural or ethnic affiliation. Some of the examples to readily identify are:

- Recruiting along political party lines

- Recruiting along religious lines

- Recruiting along tribal lines

- Recruiting along denominational linea

- Recruiting along gender lines

In all of these challenges pertaining to the system as a result of ethnicity which becomes impossible to resolve, there comes a solution from the text discussed in this paper.There are indiscriminations on the part of Christ towards the woman at the wel i.e. good communication, and value for cultural materials.

\section{CONCLUSION}

This article suggests that the mission should be a conscious enterprise whereby every element is taken into consideration. That means if the mission should be properly done, personalities involved in it must know that they are not anything other than part of the tools God is using to propagate the message. The tools for the mission are the modules of knowledge, language, values, and customs. Without having comprehensive knowledge about the words of God, one

\footnotetext{
42 Asante, Issues in African Traditional Religion, 62

43 Jerry W. Robinson, Jr and Gary Paul Green, Introduction to Community Development Theory, Practice, and Service-Learning, (London: SAGE Publications, Inc. 2011), p. 225.

44 Ibid.

45 International Labour Organization ACT/EMP Research note. Breaking barriers: Unconscious gender bias in the workplace, Bureau for Employers' Activities: August 2017

46 Ibid.
} 
cannot confidently share the message with someone let alone be able to accept individual to interact with him or her. Jesus' ability to stand with the woman was the result of the deep knowledge he had about God. Language is an important means of cultural transmission. ${ }^{47}$ This explains that everything about culture is learned. ${ }^{48}$ Christians must know that there is no other way to share the word of God with people to become believers of the faith apart from language. Schaefer reveals that Christians must admit that 'language is a critical element of culture that sets humans apart from other species" ${ }^{49}$, through which people exchange views. This does not mean using strange or unfamiliar language of the people to communicate the message of God. The language must be the one the people understand and identify themselves with. That alone is not enough, the way the language is used is also important. That means how skillful it is employed can also help the interactive process to be effective. Jesus demonstrated such a skill by exercising patience with the Samaritan woman which resulted in convincing her. That should be the hallmark of every Christian. Believers must bear in mind that values and norms are also important in the propagation of the message. Some of those values are respect, love, and care for humanity irrespective of the status either poor or rich, black or white, or stranger. Humanity must bear in mind that engaging in mission is a serious issue that calls for commitment and kind-heartedness. For these reasons human beings particularly Christians or believers must live above ethnicity and be able to meet the needs of people by giving the message of God using mission tools such as knowledge, language, values, and customs which will involve local materials and mother tongues (native languages). Once, the mission is a mandate to be executed as it has been indicated in the great commission in Matthew 28:1-20 where Jesus made an open declaration that he has every authority under the earth to give to his followers and in the same impetus he charged the followers to get on the mission, it should be diligently executed to reach the whole world with his word to bring all those who will believe in him into his fold to have eternal salvation with the Father. This paper, therefore, recommends that the mission of God is not limited to the four corners of the church bulding. Rather it is a commission to save humanity in totality. It is a mission regarding everyone devoid of colour, shape, ethnicity, profession and religion. In all these tenets towards Samaritan woman at the well, is a call for well-meaning Christian and humanity as large to do away with discrimination and treat everyone equally in all human sectors.

\section{BIBLIOGRAPHY}

Anderson R.T. and Giles, T. The Keepers, An introduction to the History and culture of the Samaritans. Peabody:Hendricks Publishing Inc., 2002.

Asante, Emmanuuel. Culture, politics and development: ethical and theological reflections on Ghanaian experience. Accra: Combert impressions, 2007. Issues in African Traditional Religion, Humanities, Ethnicity and Development: Impact on African Christianity. Accra: Sonlife, 2017.

Gadagbui, G. Yawo. Communication Disorders and Performance in Learning Environments. Accra: Bunni Business \& Multi-Media Center, 2012.

Hall, J. M. Ethnic Identity in Greek Antiquity. Cambridge: Cambridge University Press, 1997.

International Labour Organization ACT/EMP Research Note. Breaking Barriers: Unconscious Gender Bias in the

Workplace, Bureau for Employers' Activities: August 2017

Kendall, D. Sociology in Our Times 4th edition. London: Thomson Learning, Inc, 2003.

Kornblum, William. Sociology in a changing World. Chicago: university of Chicago press, 1988.

Lamin, Sanney. Translating the message: The missionary impact on culture revised and expanded. New York; USA: Orbis Books, Maryknoll, 2009.

Miller, J. C. Ethnicity in the Hebrew Bible: Problems and Prospects, 6, (2008), 170-213. https://doi.org/10.1177/1476993X07083627 Originally Published in 4 Volumes Eastbourne, England: Cook Communications Ministries, 2004.

Ott C, Strauss S. J. and. Tennent T. C. Encountering Theology of Mission: Biblical Foundations, Historical Developments, and Contemporary Issues. Grand Rapids, Michigan: Baker Academic, 2010.

Parker, Russ and Lawrence Roy. Healing and Evangelism. London: BPC Paperbacks Ltd, 1996.

Robertson, Lan. Sociology 2nd edition. London: Worth Publishers, Inc, 1981.

Robinson, J. W. Jr and Green, G. P. eds. Introduction to Community Development Theory, Practice, and ServiceLearning. London: SAGE Publications, Inc. 2011.

\footnotetext{
47 Kendall, Sociology in Our Times, 81 .

48 Lan. Robertson, Sociology 2nd edition (USA: Worth Publishers, Inc, 1981), 57

49 Schaefer, Sociology, 66
} 
Schaefer, R. T. Sociology 7th edition. New York: McGraw-Hill Companies, Inc, 2001.

Wiersbe, W. W. The Bible Exposition Commentary (Old Testament, Originally Published in 4 Volumes) Eastbourne, England: Cook Communications Ministries, 2004.

\section{Authors Bio-Data}

Livingstone Yao Torsu is an Assistant Lecturer in the Department of Theology, Heritage Christian College, Accra- Ghana. Email: rev.livingstoneyaotorsu@yahoo.com

Francis Brown is an immediate past student of Heritage Christian College, Accra-Ghana.

Email: fbx017b@hcuc.edu.gh 